\title{
FACTORS INFLUENCING TOMATO MARKETING IN ILE-IFE, OSUN STATE, NIGERIA
}

\section{UTICAJNI FAKTORI PRODAJE PARADAJZA U ILE-IFE REGIJI, DRŽAVA OSUN U NIGERIJI}

\author{
Ajibola Olajide OJEDOKUN ${ }^{*}$, Olufemi Adedotun YESUFU ${ }^{* *}$, Victoria Ayomide AYORINDE ** \\ *Department of Agriculture, Lagos State University, Epe Campus, Lagos State, Nigeria \\ ${ }^{* *}$ Department of Agricultural Economics, Obafemi Awolowo University, Ile-Ife, Osun State, Nigeria \\ e-mail: adifferentpiece@gmail.com
}

\begin{abstract}
This study was conducted to identify the factors influencing tomato marketing in Ile-Ife, Osun State, Nigeria. Primary data were collected from a total of 100 tomato marketers using a multistage sampling technique. The data were analysed using descriptive statistics, gross margin analysis and multiple regression analysis. The result obtained revealed that wholesalers had a higher gross margin than retailers. Gender, education level and transportation costs were found to influence the marketing margin of retailers, whereas household size and transportation costs influenced the marketing margin of wholesalers. The study therefore recommends that tomato marketers should be encouraged into wholesale marketing. This can be achieved by subsidization and the implementation of an efficient marketing system.
\end{abstract}

Key words: tomato, retailer, wholesaler, gross margin, determinants, Ile-Ife region

\section{REZIME}

Ova studija je sprovedena kako bi se identifikovali faktori koji utiču na prodaju paradajza u Ile-Ife, država Osun, Nigerija. Primarni podaci prikupljeni su od ukupno 100 prodavača paradajza koristeći tehniku višestrukog uzorkovanja. Podaci su analizirani koristeći opisnu statistiku, bruto maržu i višestruku regresionu analizu. Rezultat je pokazao da veletrgovci imaju veću bruto maržu od trgovaca na malo. Rezultat je takođe otkrio da su pol trgovca, nivo obrazovanja i troškovi prevoza uticali na maržu marketa na malo, dok su pol, veličina domaćinstva i troškovi prevoza uticali na maržu marketa na veliko. Studija je, dakle, preporučila da trgovce paradajzom treba motivisati da se bave prometom na veliko. To se može postići subvencionisanjem i uspostavljanjem efikasnog marketing sistema.

Ključne reči: paradajz, maloprodaja, veletrgovac, bruto marža, determinante, Ile-Ife oblast.

\section{INTRODUCTION}

Fruits and vegetables play a very important role in human nutrition and are considered a major source of essential vitamins and minerals. Vegetable production claims a substantial share (about $25 \%$ ) of the major food crops cultivated in the tropics, providing a source of livelihood to a considerable section of the population (Shehu and Mohammed, 2017). Among the different vegetables grown in Nigeria, the tomato (Solanum lycopersicum) is the most important vegetable in terms of scale of production and level of consumption (Adejobi et al., 2011). The tomato, which is grown either as a principal or secondary crop in Nigeria by most producers, can be consumed raw in salads or processed into paste or puree, which can be used for cooking savoury dishes (Haruna et al., 2012; Shehu and Mohammed, 2017).

Tomatoes and tomato-based foods provide a wide variety of nutrients and many health-related benefits to the body. The tomato contains a substantial amount of lycopene, which is a crucial antioxidant responsible for reducing the incidence of some chronic diseases such as cancer and many other cardiovascular disorders (Arab and Steck, 2000; Basu and Imrhan, 2007; Freeman and Reimers, 2010). In Nigeria, a total area of one million hectares is reportedly used for tomato cultivation, which accounts for about 18 percent of the average daily consumption of vegetables in Nigerian homes (Chidi, 2012). It is cultivated almost throughout Nigeria, thus generating employment both at urban and rural levels (Adenegan and Adeoye, 2011).
The tomato, like other agricultural products, has unique characteristics which pose certain problems to farmers, marketers (wholesalers and retailers) and final consumers alike. In addition to the lack of storage facilities, the seasonality of tomatoes exerts pressure on sales, with an attendant effect on the market price hindering large-quantity purchases by tomato sellers, thus discouraging farmers from large-scale production (Obayelu et al., 2014). Consequently, the tomato marketing system in Nigeria is poorly developed. Moreover, the Nigerian government has focused more on agricultural production with little emphasis on the follow-up marketing of vegetables such as tomatoes (Idachaba, 2000). This has resulted in reducing the profit margins of marketers who purchase vegetables mostly at the farm gate, where vegetable marketing practically begins (Haruna et al., 2012). Such costs incurred discourage vegetable marketers (namely wholesalers and retailers) from large-quantity vegetable purchases.

Tomato production and marketing involves a series of relationships and arrangements which are based on structureconduct relationship paradigms at each marketing level, i.e. from the producers to the consumers. To ensure a stable and consistent supply of tomato throughout the year, tomato marketing needs to be considered across all the marketing levels and channels. According to Haruna et al. (2012), this can best be achieved through a critical analysis of the factors influencing the profitability of tomato marketing, which would lead to maximum returns on vegetable and tomato sales for marketers. 
The purpose of this study is to identify and analyze the factors influencing the marketing margin of tomato marketers (namely wholesalers and retailers) in Nigeria.

\section{MATERIAL AND METHOD}

\section{Study Area}

This study was conducted in Ile-Ife, Osun State, which is one of the major towns in the state where tomato marketing is predominantly carried out by marketers. A multistage sampling was used in selecting respondents. The first stage involved the sampling of all major markets in Ile-Ife, whereas the second stage involved a random selection of 100 respondents from all the major markets. Therefore, a total of 100 marketers were sampled. Primary data were collected using a pretested structured questionnaire. The data on respondents' socioeconomic characteristics such as age, level of education, household size, marital status, selling price, purchase price, etc. were collected. A descriptive analysis of the data showed that there were more retailers $(68.0 \%)$ than wholesalers $(32.0 \%)$ (Table 1).

Table 1. Distribution of the respondents by type of seller

\begin{tabular}{||c|c|c||}
\hline Type of seller & Frequency & Percentage \\
\hline Wholesaler & 32 & 32.0 \\
Retailer & 68 & 68.0 \\
Total & 100 & 100.0 \\
\hline
\end{tabular}

Source: Field Survey, 2018

\section{Method of Data Analysis}

Various analytical tools and procedures were employed for this study. Descriptive statistics such as percentages, frequencies and means were employed to explain the socio-economic characteristics of the respondents. Budgetary analysis was used to determine the gross marketing margin of tomato marketers, whereas multiple regression analysis was used to determine the factors affecting the gross margin of tomato marketers.

\section{Budgetary Technique}

Budgetary technique was employed to determine the gross marketing margin of tomato marketing. Gross marketing margin measures the difference between the selling price and purchase price. The selling price was obtained by multiplying the unit price of each basket of tomato by the quantity sold, whereas the purchase price was obtained by multiplying the cost of each basket of tomato by the quantity purchased. The variable costs are those costs that vary with the total level of output and they include the cost of offloading/loading, association levy, agent fee and transportation. The addition of total variable costs and total fixed costs gives the tomato marketing costs incurred. Using the straight line method, the depreciation expenses were calculated on the fixed items, which were then used in the analysis.

The equations are:

$$
\begin{aligned}
& \mathrm{SP}=\mathrm{P}_{\mathrm{i}} \times \mathrm{Q}_{\mathrm{i}} \\
& \mathrm{PP}=\mathrm{C}_{\mathrm{i}} \times \mathrm{Q}_{\mathrm{i}} \\
& \mathrm{TMC}=\mathrm{TVC}+\mathrm{TFC} \\
& \mathrm{GMM}=\mathrm{SP}-\mathrm{PP}
\end{aligned}
$$

where GMM is the gross marketing margin, TMC is the total marketing cost, TVC is the total variable cost, TFC is the total fixed cost, SP is the selling price, $\mathrm{PP}$ is the purchased price, $\mathrm{C}_{\mathrm{i}}$ is the cost of tomato per unit of basket, $P_{i}$ is the price per unit of basket of tomato, and $\mathrm{Q}_{\mathrm{i}}$ is the price per unit quantity of tomato basket sold.

\section{Regression Model}

To identify the factors influencing the gross margin of tomato marketing, multiple regression analysis was used. The dependent variable was the computed gross margin for each marketer. A number of explanatory variables were identified and included in the model. The implicit function is given as follows:

$$
\mathrm{Y}=\mathrm{f}\left(\mathrm{X}_{1}, \mathrm{X}_{2}, \mathrm{X}_{3},---, \mathrm{X}_{6}\right)
$$

where

$\mathrm{Y}=$ Gross Marketing Margin;

$\mathrm{X}_{1}=$ Age of tomato marketer (Years);

$\mathrm{X}_{2}=$ level of education ( 1 = formal, 0 = otherwise $)$;

$\mathrm{X}_{3}=$ Household size (Number);

$\mathrm{X}_{4}=$ Marketing experience (Years);

$\mathrm{X}_{5}=$ Transportation cost $(\mathrm{N})$;

$\mathrm{X}_{6}=$ Labour cost ( $)$;

$\mathrm{e}=$ Error term.

Different regression functions such as linear, exponential, semi-log and Cobb-Douglas were used. Of the regression functions used, the Cobb-Douglas regression function was adopted as the lead equation based on the highest coefficient of determination (adjusted $\mathrm{R}^{2}$ ), with the highest F-statistics, the number of significant variables and the signs of the estimated coefficients.

\section{RESULTS AND DISCUSSION}

The mean age of retailers was 41.00 years, whereas that of wholesalers was 47.69 years. This finding indicates that respondents were mostly middle-aged and able-bodied. This is an indication of active youth involvement in tomato marketing activities. The gender distribution of the respondents presented in Table 2 show that all (100\%) the marketers (retailers and wholesalers) considered were female. This implies that tomato marketing in the study area is predominantly a female-dominated enterprise. As tomato marketing is generally accepted to be gender-biased and largely associated with females, the results obtained herein are consistent with such claims made by Adejobi et al. (2011). Previous research (Adejobi et al., 2011; Achoja and Okoh, 2013; Camillus et al., 2014) suggests that African women dominate small-scale agricultural marketing, but with less participation in the wholesaling of perishable items. The income they thus generate is mostly used to support the household and make some savings. The results obtained also indicate that the majority of the wholesalers and retailers interviewed were married ((93.8\% and $88.3 \%$, respectively). This suggests that they make use of cheap family labour, thus reducing overall labour costs. The majority of the tomato wholesalers (90.6\%) and retailers (89.7\%) were also found to have a formal education.

The mean household size of the tomato wholesalers and retailers was approximately 7 and 5 members, respectively. Although this could also suggest the employment of family labour in tomato marketing, Ogundele and Okoruwa (2006) report that a large family size does not necessarily translate into a higher use of family labour because some of the young ablebodied family members may prefer other jobs than marketing. The mean years of marketing experience of the wholesalers and retailers were 18 and 12 years, respectively. This indicates that the majority of the tomato marketers considered had been in the tomato marketing business for a long period of time. 
Table 2. Socio-economic characteristics of the tomato marketers considered

\begin{tabular}{|c|c|c|c|c|}
\hline \multirow{2}{*}{$\begin{array}{l}\text { Socio-economic } \\
\text { characteristics }\end{array}$} & \multicolumn{2}{|c|}{ Wholesalers } & \multicolumn{2}{|c|}{ Retailers } \\
\hline & Frequency & Percentage & Frequency & Percentage \\
\hline $\begin{array}{c}\text { Age } \\
25-44 \\
45-64 \\
\text { Mean (Standard } \\
\text { deviation) }\end{array}$ & $\begin{array}{c}10 \\
22 \\
47.69 \\
(6.89)\end{array}$ & $\begin{array}{l}31.3 \\
68.7\end{array}$ & $\begin{array}{c}47 \\
21 \\
41.00 \\
(8.78)\end{array}$ & $\begin{array}{l}69.1 \\
30.9\end{array}$ \\
\hline $\begin{array}{l}\text { Gender } \\
\text { Male } \\
\text { Female }\end{array}$ & $\begin{array}{c}0 \\
32\end{array}$ & $\begin{array}{c}0.0 \\
100.0\end{array}$ & $\begin{array}{c}0 \\
68\end{array}$ & $\begin{array}{c}0.0 \\
100.0\end{array}$ \\
\hline $\begin{array}{c}\text { Marital status } \\
\text { Single } \\
\text { Married }\end{array}$ & $\begin{array}{c}2 \\
30\end{array}$ & $\begin{array}{c}6.2 \\
93.8\end{array}$ & $\begin{array}{c}8 \\
60\end{array}$ & $\begin{array}{l}11.7 \\
88.3\end{array}$ \\
\hline $\begin{array}{c}\begin{array}{c}\text { Level of } \\
\text { education }\end{array} \\
\text { No formal } \\
\text { education } \\
\text { Primary } \\
\text { education } \\
\text { Secondary } \\
\text { education } \\
\text { Tertiary } \\
\text { education }\end{array}$ & $\begin{array}{c}3 \\
8 \\
19 \\
2\end{array}$ & $\begin{array}{c}9.4 \\
25.0 \\
59.4 \\
6.3\end{array}$ & $\begin{array}{c}7 \\
12 \\
47 \\
2\end{array}$ & $\begin{array}{c}10.3 \\
17.6 \\
69.1 \\
2.9\end{array}$ \\
\hline $\begin{array}{c}\text { Household size } \\
1-5 \\
6-10 \\
11-15 \\
\text { Mean (Standard } \\
\text { deviation) }\end{array}$ & $\begin{array}{c}9 \\
20 \\
3 \\
6.62(2.27)\end{array}$ & $\begin{array}{c}28.1 \\
62.5 \\
9.4\end{array}$ & $\begin{array}{c}36 \\
31 \\
1 \\
5.41(1.57)\end{array}$ & $\begin{array}{c}52.9 \\
45.6 \\
1.5\end{array}$ \\
\hline $\begin{array}{c}\text { Years of } \\
\text { marketing } \\
\text { experience } \\
1-20 \\
21-40 \\
41-60 \\
\text { Mean (Standard } \\
\text { deviation) }\end{array}$ & $\begin{array}{c}24 \\
8 \\
0 \\
18.0(6.92)\end{array}$ & $\begin{array}{c}75.0 \\
25.0 \\
0.0\end{array}$ & $\begin{array}{c}61 \\
6 \\
1 \\
12.0(8.05)\end{array}$ & $\begin{array}{c}89.7 \\
8.8 \\
1.5\end{array}$ \\
\hline
\end{tabular}

Source: Data Analysis, 2018

Analysis of the Marketing Margin of Tomato Retailers and Wholesalers

The marketing costs, estimated as the sum of variable costs and fixed costs, were $\$ 14,216.23$ and $\$ 52,126.85$ for the tomato retailers and wholesalers, respectively $(1 € \approx 420 \mathrm{~N}$ - Nigerian naira). The selling prices were $\$ 169,529.40$ and $\$ 984,625.00$ for the retailers and wholesalers, respectively. However, the purchase prices were $140,835.30$ and $\$ 805,937.50$ for the retailers and wholesalers, respectively. The gross marketing margins were $\$ 28,694.10$ and $\$ 178,687.50$ for the retailers and wholesalers, respectively. However, the net marketing margins for the retailers and wholesalers were $\$ 14,447.84$ and $\$ 126,560.65$, respectively. The results obtained indicate that the wholesalers had a higher average marketing margin than the retailers. These results are consistent with those of Obasi (2008) and Camillus et al. (2014), who reported that rice and tomato wholesalers had higher gross and net marketing margins than retailers.
Table 3. Analysis of the marketing margin of the tomato marketers considered

\begin{tabular}{|c|c|c||}
\hline \multirow{2}{*}{ Item } & Retailers & Wholesalers \\
\cline { 2 - 3 } & $\begin{array}{c}\text { Average amount } \\
\text { (N) }\end{array}$ & Average amount (N) \\
\hline Variable Costs & & \\
Cost of transportation & & \\
Cost of LG levy & $9,742.65$ & $35,437.50$ \\
Cost of & 479.12 & 993.91 \\
loading/offloading & 774.12 & $8,406.56$ \\
Cost of labour & 302.94 & $5,587.50$ \\
Cost of nylon & 2233.23 & 486.15 \\
Association levy & 92.06 & 170.37 \\
Total Variable Costs & $\mathbf{1 3 , 6 2 4 . 1 2}$ & $\mathbf{5 1 , 0 8 1 . 9 9}$ \\
& & \\
Fixed Costs & & \\
Depreciation cost & 146.03 & 233.66 \\
Space rent & 446.08 & 811.20 \\
Total fixed costs & $\mathbf{5 9 2 . 1 1}$ & $\mathbf{1 , 0 4 4 . 8 6}$ \\
Total Marketing Costs & $\mathbf{1 4 , 2 1 6 . 2 3}$ & $\mathbf{5 2 , 1 2 6 . 8 5}$ \\
Purchase Price (PP) & $140,835.30$ & $805,937.50$ \\
Selling Price (SP) & $169,529.40$ & $984,625.00$ \\
Gross Marketing & $\mathbf{2 8 , 6 9 4 . 1 0}$ & $\mathbf{1 7 8 , 6 8 7 . 5 0}$ \\
Margin (GMM) & $\mathbf{1 4 , 4 4 7 . 8 7}$ & $\mathbf{1 2 6 , 5 6 0 . 6 5}$ \\
Net Marketing Margin & $\mathbf{1 4 0}$ & \\
(NMM) & $\mathbf{1 6 . 9 3 \%}$ & $\mathbf{1 8 . 1 5 \%}$ \\
Percentage Marketing & & \\
Margin & & \\
\hline \hline
\end{tabular}

Source: Data Analysis, 2018

Factors Affecting the Marketing Margin of Tomato Marketers

The factors affecting the marketing margin of tomato retailers and wholesalers are shown in Table 4. The model employed had adjusted $\mathrm{R}^{2}$ values of 0.9892 and 0.9854 for retailers and wholesalers respectively, indicating $98.92 \%$ and $98.54 \%$ of variation in the marketing margin of tomato retailers and wholesalers (as expressed by the explanatory variables included in the model). The models for the two different types of marketers were significant at the $1 \%$ level, suggesting the models' goodness of fit. A total of six explanatory variables were included in the models, i.e. three per each type of tomato marketers considered: gender, level of education and transportation cost for the retailers, and gender, household size and transportation cost for the wholesalers.

The results obtained show that the gender coefficients for both tomato retailers and wholesalers were positive and statistically significant at the $1 \%$ and $5 \%$ levels, respectively. This implies that an increase in the number of female retailers and wholesalers will lead to an increase in the marketing margin accruable to tomato marketers. Furthermore, the coefficients of transportation costs for both types of tomato marketers considered were negative and statistically significant at the $10 \%$ and $1 \%$ levels, respectively. This implies that the marketing margin accruable to tomato retailers and wholesalers would reduce with increased transportation costs.

Although the education level coefficient for the tomato retailers was positively significant at the $5 \%$ level, the coefficient of household size was negatively significant for the tomato wholesalers at the $1 \%$ level. This indicates that the net 
marketing margin accruable to the tomato retailers would increase with higher levels of their formal education, whereas a decrease in the number of wholesalers' household members would increase their marketing margin. The positive relationship between the retailers' level of education and their net marketing margin is consistent with the results of Obasi (2008), who observed that higher levels of marketers' education improved their marketing strategy and compliance with marketing conditions.

Table 4. Factors influencing the marketing margin of the tomato marketers considered

\begin{tabular}{||c|c|c|c|c||}
\hline \hline \multirow{2}{*}{ Variable } & \multicolumn{2}{|c|}{ Retailer } & \multicolumn{2}{c||}{ Wholesaler } \\
\cline { 2 - 5 } & Coefficient & $\mathbf{t}$ & Coefficient & t \\
\hline Gender & 8.726787 & $3.91^{* * *}$ & 8.410947 & $2.13^{* *}$ \\
\hline Household size & .6684644 & 1.51 & -1.165524 & $-2.94^{* * *}$ \\
\hline $\begin{array}{c}\text { Level of } \\
\text { education }\end{array}$ & .4620632 & $1.84^{* *}$ & .6428941 & 0.89 \\
\hline $\begin{array}{c}\text { Years of } \\
\text { experience }\end{array}$ & -.4279191 & -1.55 & .9240114 & 1.59 \\
\hline $\begin{array}{c}\text { Transportation } \\
\text { cost }\end{array}$ & -.2743932 & $-1.66^{*}$ & -.1958655 & $-2.79 * * *$ \\
\hline Labour cost & .0243881 & 0.49 & -.0169211 & -0.18 \\
\hline R ${ }^{2}$ & 0.9906 & & 0.9891 & \\
\hline Adj R & 0.9892 & & 0.9854 & \\
\hline F-value & 693.88 & & 271.87 & \\
\hline
\end{tabular}

Source: Data Analysis, 2018

***=Significant at $1 \%$;**=Significant at 5\%; * = Significant at $10 \%$

\section{CONCLUSION}

This study was conducted to identify the factors influencing tomato marketing in Ile-Ife, Osun State, Nigeria. The results obtained revealed that wholesalers had a higher gross margin than retailers. Gender, education level and transportation costs were found to influence the marketing margin of retailers, whereas household size and transportation costs influenced the marketing margin of wholesalers. The present study therefore recommends that tomato marketers should be encouraged into wholesale marketing. This can be achieved by subsidization and the implementation of an efficient marketing system. Tomato marketers should also be informed about the benefits of education and how it can be harnessed towards achieving maximum returns. Moreover, the government should assist tomato marketers by improving the transportation system in order to reduce transportation costs and transportation-related tomato quality losses.

\section{REFERENCES}

Achoja F. O. and Okoh R. N. (2014). Post-Harvest Properties of Tomato and Effect on Its Marketing Efficiency. Turkish Journal of Agricultural and Natural Sciences, 1(1): 52 - 58

Adejobi A. O., Babatunde R. O. and Idowu E. O. (2011). Weight and measurement issues in retail marketing of fresh tomatoes: evidence from Osun State. Journal of Agricultural Science, 6 (4): $20-26$

Adenegan K. O. and Adeoye I. B. (2011). Price Analysis of Tomato in Rural and Urban Retail Markets of Oyo State. International Journal of Agricultural Economics and Rural Development, 4(2): 90 - 96

Arab L. and S. Steck (2000). Lycopene and cardiovascular disease. American Journal of Clinical Nutrition, 71: 1691S $1695 \mathrm{~S}$

Basu, A. and V. Imrhan (2007). Tomatoes versus lycopene in oxidative stress and carcinogenesis: conclusions from clinical trials. European Journal of Clinical Nutrtion, 61(3): 295 - 303

Camillus A. W. Stephen O. M., Alexander A., Lydia A. and Zu Kwame S. A. (2014). Economics of Tomato Marketing in Ashanti region, Ghana. RJOAS, 2(26): 3 - 13

Chidi, A. (2012). Tomato, nutritious vegetable. Seventeen Nigerian Economic Summit. Manufacturing today Nigeria. Alafrican post web team. Pp1-3.

Freeman B. B., and Reimers K. (2010). Tomato consumption and health: emerging benefits. American Journal of Lifestyle Medicine, 1 - 11

Haruna, U., Sani., M.H., Danwanka., H.A. and Adejo. (2012). Economic Analysis of Fresh Tomato Marketers in Bauchi Metropolis of Bauchi State, Nigeria. Nigerian Journal of Agriculture, Food and Environment, 8(3): 1 - 8

Idachaba, F. S. (2000). Food Policy in Nigeria. Agricultural Research Bulleting, 1:162.

Obasi, I. O. (2008). Structure, Conduct and Performance of Rice Markets in Abia State, Nigeria. (Unpublished Master's Thesis), Michael Okpara University of Agriculture, Umudike, Nigeria.

Obayelu A. E., Arowolo A. O., Ibrahim S. B. and Croffie A. Q. (2014). Economics of Fresh Tomato Marketing in Kosofe Local Government Area of Lagos State, Nigeria. Nigerian Journal of Agricultural Economics, 4(1): 58 - 67

Ogundele A. O. and Okoruwa V. O. (2006). Technical Efficiency Differentials in Rice Production Technology in Nigeria. African Economic Consortium, Research Paper No. 154

Shehu A. S. and Mohammed A. S. (2017). Economic Analysis of Tomato Marketing in Ilorin Metropolis, Kwara State, Nigeria. Journal of Agricultural Sciences, 62(2): 179 - 191

Received: 08. 05. 2020.

Accepted: 01. 06. 2020. 